\title{
Molecular Characterization of Bacterial Isolates and Physicochemical Assessment of Well Water Samples from Hostels at Osekita, Iworoko-Ekiti, Ekiti State
}

\author{
Odeyemi A. T. ${ }^{1, *}$, Ayantola K. J. ${ }^{2}$, Peter S. ${ }^{1}$ \\ ${ }^{1}$ Microbiology Department, Ekiti State University, Ado-Ekiti, Nigeria \\ ${ }^{2}$ Science Laboratory Technology Department, Ekiti State University, Ado-Ekiti, Nigeria \\ *Corresponding author: adebowaleodeyemi@gmail.com
}

\begin{abstract}
Drinking water has been a major issue in many student hostels at Osekita in Ekiti State University, Ado-Ekiti, Nigeria and majority of the student's populace do not have access to portable water. Only few students can afford and rely on treated water particularly for consumption therefore, underground water (well water) serve as the major source of both drinking water and domestic water used in their hostels by determining the total bacterial and coliform counts, antibiotic susceptibility of the isolated bacteria, plasmid analysis of the multiple-resistant bacteria isolates, gene sequencing of the plasmid possessed bacteria and physicochemical properties of the well water samples using standard techniques. Twelve well water samples were obtained from hostels at Osekita and analyzed. The total bacteria and coliform counts ranged from $1.0 \times 10^{5} \mathrm{CFU} / \mathrm{ml}$ to $9.7 \times 10^{5}$ and $1.2 \times 10^{4} \mathrm{CFU} / \mathrm{ml}$ to $6.7 \times 10^{5} \mathrm{CFU} / \mathrm{ml}$ respectively. Eight genera of bacteria were isolated from the water samples; Streptococcus spp., Pseudomonas aeruginosa, Micrococcus spp., Escherichia coli, Enterobacter spp., Klebsiella spp., Proteus spp. and Staphylococcus aureus. Streptococcus spp. showed the highest occurrence of $28.57 \%$ while Proteus spp. and Staphylococcus aureus showed the least occurrence of $3.57 \%$ among the isolated bacteria. About $68 \%$ of the isolated bacteria were resistance to at least four of the ten antibiotics used, some of which inhabited extra-chromosomal DNA (plasmid) with molecular weight of $3.0 \mathrm{~Kb}$. Gene sequencing clearly revealed the two organisms subjected to molecular characterization to be Escherichia coli strain s1428 and Enterobacter aerogenes strain 341. Gene sequencing revealed the resistant genes not only located on plasmids but also encoded on the organisms DNA. The physicochemical parameters were within the WHO recommended standard for portable water. Based on the microbiological standard, the water samples analyzed are not safe for consumption.
\end{abstract}

Keywords: coliform, antibiotic susceptibility, drinking water, plasmid, gene sequencing

Cite This Article: Odeyemi A. T., Ayantola K. J., Peter S., "Molecular Characterization of Bacterial Isolates and Physicochemical Assessment of Well Water Samples from Hostels at Osekita, Iworoko-Ekiti, Ekiti State" American Journal of Microbiological Research, vol. 6, no. 1 (2018): 22-32. doi: 10.12691/ajmr-6-1-4.

\section{Introduction}

Water is essential in the life of all living organisms from the simplest plants and microorganisms to the most complex living system known as human body [1]. Water is significant due to its unique chemical and physical properties and is known to be the most abundant compound (70\%) on earth $[2,3]$.

Drinking water has been a major issue in many countries like Nigeria [4] and majority of the rural populace in Nigeria do not have access to portable water. Only few people can afford and rely on purified and treated water particularly for consumption therefore, underground water (well water) serve as the major source of both drinking water and domestic water used in local population of Nigeria [5].

Contaminated wells can lead to the spread of various water-borne diseases. Dug and driven wells are relatively easy to contaminate; for instance, most dug wells are unreliable in the majority of the United States [6]. Most of the bacteria, viruses, parasites, and fungi that contaminate well water comes from fecal material from humans and other animals, for example from on-site sanitation systems (such as pit latrines and septic tanks). Common bacterial contaminants include E. coli, Salmonella, Shigella, Micrococcus spp., Pseudomonas spp., Streptococcus spp., Klebsiella spp., and Campylobacter jejuni. Pathogenic bacteria of human origin typically cause diseases of the gastrointestinal tract such as typhoid, paratyhoid fever, dysentery, diarrhea, cholera and one of the most common bacterial pathogens found in domestic water is Salmonella [7].

Bacteria however developed different mechanisms to render ineffective the antibiotics used against them. The genes encoding these defence mechanisms are located on bacterial chromosomes or on extra-chromosomal plasmids, and are transmitted to the next generation (vertical gene transfer). Genetic elements such as plasmids can also be exchanged among bacteria of different taxonomic affiliation (horizontal gene transfer) [8]. Microbial transformation 
with plasmid DNA is neither parasitic nor symbiotic in nature, because each implies the presence of an independent species living in a commensal or detrimental state with the host. Rather, plasmids provide a mechanism for horizontal gene transfer within a population of microbes and typically provide a selection advantage under a given environmental condition. Plasmids may carry genes that provide resistance to naturally occurring antibiotics in a competitive environmental niche, or the proteins produced may act as toxins under similar circumstances.

Realizing that well water in hostels at Osekita, Ekiti State is widely used in domestic household by the students of Ekiti State University, Ado-Ekiti. This research is designed to know the portability and qualities of the water samples by determining plasmid and gene sequence of multiple resistant bacteria from the well water samples of hostels at Osekita, Iworoko-Ekiti.

\section{Materials and Methods}

\subsection{Collection of Samples}

Water samples were collected with the sterile sample bottles from different wells at hostels in Osekita, Iworoko-Ekiti, Ekiti State and were taken to the laboratory for analysis within $4 \mathrm{~h}$ of collection.

\subsection{Microbiological Analysis}

Ten fold dilutions of well water samples were done and $1 \mathrm{ml}$ dilution factors of $10^{-3}$ and $10^{-5}$ were plated. The prepared molten agar (about $45^{\circ} \mathrm{C}$ ) was poured into each plate containing the diluted inoculums, gently swirled and allowed to solidify [9]. The cultured plates were incubated for 24 hours at $37^{\circ} \mathrm{C}$. After the incubation period, plates with growth were estimated and distinct colonies on the plates were aseptically sub-cultured onto freshly prepared solidified nutrient agar and incubated at $37^{\circ} \mathrm{C}$ for 24 hours; stored in freshly prepared agar slants until use. Pure isolates were observed for morphological and molecular characteristics. These pure bacterial isolates were then subjected to biochemical tests for presumptive identification of the bacterial isolates and antibiotic sensitivity test with aid of Mueller Hinton agar and antibiotic discs. The diameter zone of inhibition was measured and compared with the standard antibiotic chart to determine which is susceptible, intermediate or resistance.

\subsection{Inoculation of Test Organisms on Plates}

Under aseptic conditions, sterile cotton swabs dipped into each inoculum suspension, pressed slightly and rotated inside the tube just above the fluid level, to remove excess culture fluid, were swabbed over the surface of the freshly prepared and solidified sterile Mueller Hinton agar medium in three directions, rotating the plate approximately 60 degree to ensure even distribution of organisms as described by [10].

\subsection{Antibiotic Susceptibility Test}

The antibiotic sensitivity of the bacterial isolates was tested with using the disc diffusion method on Mueller
Hinton Agar. The antibiotic discs were aseptically, carefully and firmly placed on the inoculated plates using sterile forceps. The plates were then incubated inverted for 24 hours at a temperature of 37C. After incubation, the plates were examined for growth and diameters of zone inhibition were measured and the results were interpreted with reference to [11].

Isolates were screened for resistance to AMX-Amoxicillin

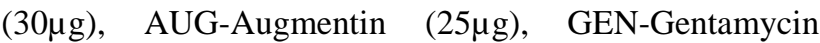

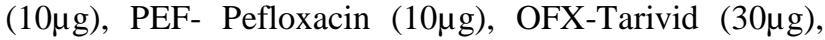

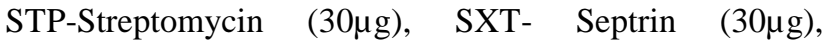

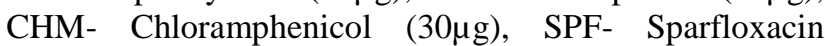
$(10 \mu \mathrm{g})$, CPX- Ciprofloxacin $(10 \mu \mathrm{g})$, ROC- Rocephin $(25 \mu \mathrm{g})$, ERY - Erythromycin $(10 \mu \mathrm{g})$, APX- Ampiclox

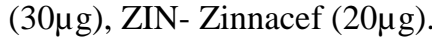

\subsection{Plasmid Profiling}

Plasmid DNA was isolated by modification of the technique described by [12]. These techniques are used for isolation of plasmids for both Gram-negative and Gram-positive bacteria. The technique used majorly for isolation of Gram-negative negative bacterial plasmids is known as TENS. The TENS composition comprises of Tris $25 \mathrm{mM}$, EDTA $10 \mathrm{mM}, \mathrm{NaOH} 0.1 \mathrm{M}$ and SDS $0.5 \%$. The solution contain Tris buffer that maintains the optimum pH; EDTA act as chelating agent; $\mathrm{NaOH}$ helps by increasing osmotic pressure, and SDS (Sodium Dodecyl Sulphate) act as a detergent which actually breaks the cell wall to release its content.

Plasmids were isolated using the QIAGEN Plasmid Purification mini kit and the integrity of the extracted plasmid was checked on a 1\% Agarose gel ran to confirm amplification. The buffer (1XTAE buffer) was prepared and subsequently used to prepare $1 \%$ agarose gel. The suspension was boiled in a microwave for 5 minutes. The molten agarose was allowed to cool to $60^{\circ} \mathrm{C}$ and stained with $3 \mu \mathrm{l}$ of $0.5 \mathrm{~g} / \mathrm{ml}$ ethidium bromide (which absorbs invisible UV light and transmits the energy as visible orange light). A comb was inserted into the slots of the casting tray and the molten agarose was poured into the tray. The gel was allowed to solidify for 20 minutes to form the wells. The 1XTAE buffer was poured into the gel tank to barely submerge the gel. Two microliter $(2 \mu \mathrm{l})$ of $10 \mathrm{X}$ blue gel loading dye (which gives colour and density to the samples to make it easy to load into the wells and monitor the progress of the gel) was added to $10 \mu \mathrm{l}$ of each PCR product and loaded into the wells after the 100-3000bp DNA ladder was loaded. The gel was electrophoresed at $120 \mathrm{~V}$ for 45 minutes visualized by ultraviolet trans-illumination and photographed. The sizes of the PCR products were estimated by comparison with the mobility of the molecular weight ladder that was ran alongside experimental samples in the gel.

\subsection{Molecular Identification of Isolates}

\subsubsection{DNA Extraction}

DNA was extracted using the principle stated by [13]. Single colonies grown on medium were transferred to $1.5 \mathrm{ml}$ of liquid medium and cultures were grown on a shaker for $48 \mathrm{~h}$ at $28^{\circ} \mathrm{C}$. After this period, cultures were 
centrifuged at $4600 \mathrm{~g}$ for $5 \mathrm{~min}$. The resulting pellets were re-suspended in $520 \mu \mathrm{l}$ of TE buffer (10 mMTris-HCl, $1 \mathrm{mM}$ EDTA, pH 8.0). Fifteen microliters of $20 \%$ SDS and $3 \mu \mathrm{l}$ of Proteinase K $(20 \mathrm{mg} / \mathrm{ml})$ were then added. The mixture was incubated for 1 hour at $37^{\circ} \mathrm{C}$, then $100 \mu$ of 5 $\mathrm{M} \mathrm{NaCl}$ and $80 \mu \mathrm{L}$ of a $10 \%$ CTAB solution in $0.7 \mathrm{M}$ $\mathrm{NaCl}$ were added and votexed. The suspension was incubated for $10 \mathrm{~min}$ at $65^{\circ} \mathrm{C}$ and kept on ice for $15 \mathrm{~min}$. An equal volume of chloroform: isoamyl alcohol (24:1) was added, followed by incubation on ice for $5 \mathrm{~min}$ and centrifugation at $7200 \mathrm{~g}$ for $20 \mathrm{~min}$. The aqueous phase was then transferred to a new tube and isopropanol (1: 0.6) was added and DNA precipitated at $-20^{\circ} \mathrm{C}$ for $16 \mathrm{~h}$. DNA was collected by centrifugation at $13000 \mathrm{~g}$ for $10 \mathrm{~min}$, washed with $500 \mu \mathrm{l}$ of $70 \%$ ethanol, air-dried at room temperature for approximately three hours and finally dissolved in $50 \mu \mathrm{l}$ of TE buffer.

\subsubsection{Polymerase Chain Reaction}

PCR sequencing preparation cocktail consisted of $10 \mu \mathrm{l}$ of 5x GoTaq colourless reaction, $3 \mu \mathrm{l}$ of $25 \mathrm{mM} \mathrm{MgCl} 2,1$ $\mu \mathrm{l}$ of $10 \mathrm{mM}$ of dNTPs mix, $1 \mu \mathrm{l}$ of 10 pmol each $27 \mathrm{~F}$ 5'- AGA GTT TGA TCM TGG CTC AG-3' and - 1525R, 5'-AAGGAGGTGATCCAGCC-3' primers and 0.3units of Taq DNA polymerase (Promega, USA) made up to $42 \mu$ with sterile distilled water $8 \mu \mathrm{l}$ DNA template. PCR was carried out in a GeneAmp 9700 PCR System Thermalcycler (Applied Biosystem Inc., USA) with a Pcr profile consisting of an initial denaturation at $94^{\circ} \mathrm{C}$ for 5 min; followed by a 30 cycles consisting of $94^{\circ} \mathrm{C}$ for $30 \mathrm{~s}$, $50^{\circ} \mathrm{C}$ for $60 \mathrm{~s}$ and $72^{\circ} \mathrm{C}$ for 1 minute 30 seconds; and a final termination at $72^{\circ} \mathrm{C}$ for 10 mins and chilled at $4^{\circ} \mathrm{C}$. The integrity of the amplified about $1.5 \mathrm{Mb}$ gene fragment was checked on a $1.5 \%$ Agarose gel ran to confirm amplification. The buffer (1XTAE buffer) was prepared and subsequently used to prepare $1.5 \%$ agarose gel.

\subsubsection{Purification of Amplified Product}

After gel integrity, the amplified fragments were ethanol purified in order to remove the PCR reagents. Briefly, $7.6 \mu \mathrm{l}$ of sodium acetate $3 \mathrm{M}$ and $240 \mu \mathrm{l}$ of $95 \%$ ethanol were added to each about $40 \mu$ PCR amplified product in a new sterile $1.5 \mu \mathrm{l}$ tube eppendorf, mix thoroughly by vortexing and keep at $-20^{\circ} \mathrm{C}$ for at least 30 min. Centrifugation for $10 \mathrm{~min}$ at $13000 \mathrm{~g}$ and $4^{\circ} \mathrm{C}$ followed by removal of supernatant (invert tube on trash once) after which the pellet were washed by adding $150 \mu \mathrm{l}$ of $70 \%$ ethanol and mix then centrifuge for 15 min at $7500 \mathrm{~g}$ and $4^{\circ} \mathrm{C}$. Again remove all supernatant (invert tube on trash) and invert tube on paper tissue and let it dry in the fume hood at room temperature for 10-15 min. then resuspended with $20 \mu \mathrm{l}$ of sterile distilled water and kept in $-20^{\circ} \mathrm{C}$ prior to sequencing. The purified fragment was checked on a $1.5 \%$ Agarose gel ran on a voltage of $110 \mathrm{~V}$ for about $1 \mathrm{hr}$ as previous, to confirm the presence of the purified product and quantified using a nano drop of model 2000 from thermo scientific.

\subsubsection{Sequencing}

The amplified fragments were sequenced using a Genetic Analyzer 3130xl sequencer from Applied Biosystems using manufacturers' manual while the sequencing kit used was that of BigDye terminator v3.1 cycle sequencing kit. Bio- Edit software and MEGA 6 were used for all genetic analysis. Samples were first identified via sequencing and blasting of the $16 \mathrm{~S}$ ribosomal RNA.

\subsection{Molecular Analysis of Antibiotic Resistance-coding Genes via PCR}

\subsubsection{Molecular Analysis of ESBL-coding Genes}

Molecular investigations of antibiotic resistance gene in our isolates were by simple PCR on the extracted DNA using specific primers to recognize certain antibiotic resistance regions. Reaction cocktail used for all PCR per primer set included (Reagent Volume $\mu \mathrm{l}$ ) - 5X PCR SYBR green buffer (2.5), MgCl2 (0.75), 10pM DNTP (0.25), $10 \mathrm{pM}$ of each forward and backwards primer (0.25), 8000U of taq DNA polymerase (0.06) and made up to 10.5 with sterile distilled water to which $2 \mu$ template was added. Buffer control was also added to eliminate any probability of false amplification Table below shows the primer sequence and PCR profile used in amplifying each fragment. PCR was carried out in a GeneAmp 9700 PCR System Thermalcycler (Applied Biosystem Inc., USA) using the appropriate profile as designed for each primer pair.

\subsubsection{Agarose Gel Electrophoresis}

Agarose gel (1.5\%) prepared as previous was used to confirm positive amplification. Ten microlitres of each PCR product were loaded into the wells with the 100bp DNA ladder loaded. The gel was electrophoresed at $120 \mathrm{~V}$ for 45 minutes visualized by ultraviolet trans-illumination and photographed. The sizes of the PCR products were estimated by comparison with the mobility of a 100bp molecular weight ladder that was ran alongside experimental samples in the gel.

\begin{tabular}{|c|c|c|c|}
\hline \multicolumn{4}{|c|}{ Primer sequence used in DNA extraction of multiple antibiotic resistance genes } \\
\hline Antibiotic & Gene & Primer sequence 5'-3' & Procedure \\
\hline \multirow[t]{2}{*}{ Streptomycin } & aadAF & TATCCAGCTAAGCGCGAACT & \multirow{2}{*}{$\begin{array}{l}\text { An initial denaturing } 5 \mathrm{~min} \text { at } 94^{\circ} \mathrm{C} \text {, then } 35 \text { cycles of } 94^{\circ} \mathrm{C} \text { for } 30 \mathrm{~s} \text {, } \\
56^{\circ} \mathrm{C} \text { for } 30 \mathrm{~s} 72^{\circ} \mathrm{C} \text { for } 60 \mathrm{~s} \text { and terminate at } 72^{\circ} \mathrm{C} \text { for } 10 \mathrm{~min}\end{array}$} \\
\hline & aadAR & ATTTGCCGACTACCTTGGTC & \\
\hline \multirow[t]{2}{*}{ Gentamycin } & aаc(3)-IVF & CTTCAGGATGGCAAGTTGGT & \multirow{2}{*}{$\begin{array}{l}\text { An initial denaturing } 5 \mathrm{~min} \text { at } 94^{\circ} \mathrm{C} \text {, then } 35 \text { cycles of } 94^{\circ} \mathrm{C} \text { for } 30 \mathrm{~s} \\
55^{\circ} \mathrm{C} \text { for } 30 \mathrm{~s} \text { and } \\
72^{\circ} \mathrm{C} \text { for } 60 \mathrm{~s} \text { and terminate at } 72^{\circ} \mathrm{C} \text { for } 10 \mathrm{~min}\end{array}$} \\
\hline & aac(3)-IVR & TCATCTCGTTCTCCGCTCAT & \\
\hline \multirow[t]{2}{*}{$\begin{array}{l}\text { (sparfloxacin) } \\
\text { fluoroquinolone }\end{array}$} & qnrAF & GGGTATGGATATTATTGATAAAG & \multirow{2}{*}{$\begin{array}{l}\text { An initial denaturing } 5 \mathrm{~min} \text { at } 94^{\circ} \mathrm{C} \text {, then } 35 \text { cycles of } 94^{\circ} \mathrm{C} \text { for } 60 \mathrm{~s} \text {, } \\
50^{\circ} \mathrm{C} \text { for } 40 \mathrm{~s} \text { and } 72^{\circ} \mathrm{C} \text { for } 60 \mathrm{~s} \text {. and terminate at } 72^{\circ} \mathrm{C} \text { for } 10 \mathrm{mins}\end{array}$} \\
\hline & qnrA R & CTAATCCGGCAGCACTATTTA & \\
\hline \multirow[t]{2}{*}{ chloroamphenicol } & catA1F & AGTTGCTCAATGTACCTATAACC & \multirow{2}{*}{$\begin{array}{l}\text { An initial denaturing } 5 \mathrm{~min} \text { at } 94^{\circ} \mathrm{C} \text {, then } 35 \text { cycles of } 94^{\circ} \mathrm{C} \text { for } 60 \mathrm{~s} \text {, } \\
54^{\circ} \mathrm{C} \text { for } 40 \mathrm{~s} \text { and } 72^{\circ} \mathrm{C} \text { for } 60 \mathrm{~s} \text {. and terminate at } 72^{\circ} \mathrm{C} \text { for } 10 \mathrm{mins}\end{array}$} \\
\hline & catA1R & TTGTAATTCATTAAGCATTCTGCC & \\
\hline
\end{tabular}




\subsection{Physicochemical Analysis of Water Samples}

The temperature of the water samples were taken at the sites of collection using a simple thermometer calibrated in ${ }^{\circ} \mathrm{C}$ as described by $[14,15]$. Electrical conductivity was measured with a CDM 83 conductivity meter (Radio Meter A/S Copenhagen, Denmark). Turbidity and $\mathrm{pH}$ were determined at site using Water Proof Scan 3+ Double Junction and HI 98311-HI 98312 (Hanna) (Wagtech International, UK). The samples were stored under deep freezing conditions or temperature of ${ }^{\circ} 20$ ntil it was analyzed. Other physicochemical characteristics determined were hardness determined by titrimetry; total dissolved solid and total suspended solid were determined by gravimetric method; acidity and alkalinity were determined by titrimetry; both nitrate and sulphate were determined colorimetrically by Spectronic-20 (Gallenkamp, UK) as described by [16]. Calcium and magnesium were analyzed using EDTA titration method.

\section{Results}

\subsection{Estimation of Bacteria}

The bacteriological assessment of water samples obtained from hand-dug wells in hostels at Osekita, Iworoko-Ekiti was examined. Total bacterial and coliform counts for 12 well water samples ranged from $1.0 \times 10^{5}$ to $9.7 \times 10^{5}$ and $1.2 \times 10^{4}$ to $6.7 \times 10^{5} \mathrm{CFU} / \mathrm{ml}$ respectively (Table 1 and Table 2).

Twenty eight bacterial isolates were recovered from the well water samples and percentage distribution of each genera of bacteria isolated are depicted below in Table 3; Streptococcus spp. showed highest frequency of $28.6 \%$, followed by Pseudomonas spp. with 17.9\%, Micrococcus spp. and Escherichia coli both had 14.3\%, Enterobacter aerogenes with $10.7 \%$, Klebsiella aerogenes with $7.1 \%$, Proteus sp. and Staphylococcus sp. both had 3.6\% (Table 3).

Table 1. Total bacterial count (CFU/ml) of water samples

\begin{tabular}{cccc}
\hline \multirow{2}{*}{$/ \mathrm{N}$} & Samples & \multicolumn{2}{c}{ Bacterial counts } \\
\cline { 3 - 4 } & & $10^{-3}$ & $10^{-4}$ \\
\hline 1 & $\mathrm{~A}_{1}$ & $1.4 \times 10^{5}$ & $1.0 \times 10^{5}$ \\
3 & $\mathrm{~A}_{2}$ & $8.1 \times 10^{5}$ & $2.0 \times 10^{5}$ \\
4 & $\mathrm{~A}_{3}$ & $9.5 \times 10^{5}$ & $4.2 \times 10^{5}$ \\
5 & $\mathrm{~A}_{4}$ & $6.7 \times 10^{5}$ & $2.4 \times 10^{5}$ \\
6 & $\mathrm{~A}_{5}$ & $6.4 \times 10^{5}$ & $1.3 \times 10^{5}$ \\
7 & $\mathrm{~A}_{6}$ & $4.9 \times 10^{5}$ & $1.9 \times 10^{5}$ \\
8 & $\mathrm{~A}_{7}$ & $7.1 \times 10^{5}$ & $2.5 \times 10^{5}$ \\
9 & $\mathrm{~A}_{8}$ & $9.7 \times 10^{5}$ & $3.2 \times 10^{5}$ \\
10 & $\mathrm{~A}_{9}$ & $4.1 \times 10^{5}$ & $1.2 \times 10^{5}$ \\
11 & $\mathrm{~A}_{10}$ & $3.8 \times 10^{5}$ & $1.7 \times 10^{5}$ \\
12 & $\mathrm{~A}_{11}$ & $6.6 \times 10^{5}$ & $1.2 \times 10^{5}$ \\
\hline
\end{tabular}

Keys: A (Osekita), $A_{1}$ (Fufu castle), $A_{2}$ (Bimbo villa), $A_{3}$ (Heritage), $A_{4}$ (God's gift), $A_{5}$ (Darem), $A_{6}$ (Sahadat), $A_{7}$ (Daylight), $A_{8}$ (Deyem), $A_{9}$ (Mercy domain), $\mathrm{A}_{10}$ (Flochris hall), $\mathrm{A}_{11}$ (HPL), $\mathrm{A}_{12}$ (Goshen).
Table 2. Total coliform counts of water samples

\begin{tabular}{cccc}
\hline \multirow{2}{*}{$/ \mathrm{N}$} & Samples & \multicolumn{2}{c}{ Coliform counts } \\
\cline { 3 - 4 } & & $10^{-3}$ & $10^{-4}$ \\
\hline 1 & $\mathrm{~A}_{1}$ & $2.0 \times 10^{5}$ & $1.1 \times 10^{5}$ \\
2 & $\mathrm{~A}_{2}$ & $4.1 \times 10^{5}$ & $1.4 \times 10^{5}$ \\
3 & $\mathrm{~A}_{3}$ & $3.5 \times 10^{5}$ & $2.1 \times 10^{5}$ \\
4 & $\mathrm{~A}_{4}$ & $6.7 \times 10^{5}$ & $2.4 \times 10^{5}$ \\
5 & $\mathrm{~A}_{5}$ & $2.1 \times 10^{5}$ & $1.3 \times 10^{5}$ \\
6 & $\mathrm{~A}_{6}$ & $3.3 \times 10^{4}$ & $1.2 \times 10^{5}$ \\
7 & $\mathrm{~A}_{7}$ & $6.7 \times 10^{5}$ & $2.3 \times 10^{5}$ \\
8 & $\mathrm{~A}_{8}$ & $2.2 \times 10^{5}$ & $1.1 \times 10^{5}$ \\
9 & $\mathrm{~A}_{9}$ & $9.0 \times 10^{4}$ & $4.0 \times 10^{4}$ \\
10 & $\mathrm{~A}_{10}$ & $3.7 \times 10^{4}$ & $2.0 \times 10^{4}$ \\
11 & $\mathrm{~A}_{11}$ & $2.2 \times 10^{4}$ & $1.5 \times 10^{4}$ \\
12 & $\mathrm{~A}_{12}$ & $3.8 \times 10^{4}$ & $1.2 \times 10^{4}$ \\
\hline
\end{tabular}

Keys: A (Osekita), $A_{1}$ (Fufu castle), $A_{2}$ (Bimbo villa), $A_{3}$ (Heritage), $A_{4}$ (God's gift), $A_{5}$ (Darem), $A_{6}$ (Sahadat), $A_{7}$ (Daylight), $A_{8}$ (Deyem), $A_{9}$ (Mercy domain), $\mathrm{A}_{10}$ (Flochris hall), $\mathrm{A}_{11}$ (HPL), $\mathrm{A}_{12}$ (Goshen).

Table 3. Percentage distribution of isolated bacteria from water samples

\begin{tabular}{llcc}
\hline S/N & Organisms & Numbers & Frequency (\%) \\
\hline 1 & Streptococcus spp. & 8 & 28.6 \\
2 & Pseudomonas aeruginosa & 5 & 17.9 \\
3 & Micrococcus spp. & 4 & 14.3 \\
4 & Escherichia coli & 4 & 14.3 \\
5 & Enterobacter aerogenes & 3 & 10.7 \\
6 & Klebsiella aerogenes & 2 & 7.1 \\
7 & Proteus sp. & 1 & 3.6 \\
8 & Staphylococcus aureus & 1 & 3.6 \\
& Total & 28 & 100 \\
\hline
\end{tabular}

\subsection{Antibiotic Resistant Values}

Table 4 and Table 5 shows the multi-drug resistance (MDR) pattern of the 28 bacterial isolates; only $3.6 \%$ of the isolates showed resistance to six of the antibiotics without any resistant isolate to all the antibiotics used, 32.1\% of the isolates were resistant to five antibiotics which had the highest percentage resistance and only $14.3 \%$ of the isolates resisted the effect of four of the ten antibiotics used.

Multi-drug resistance (MDR) pattern of Gram negative bacteria isolated revealed Pseudomonas aeruginosa shows the highest resistance pattern resisting the effect of 5-6 antibiotics of the ten different antibiotic drugs tested while Enterobacter aerogenes shows the lowest resistance pattern resisting the effect of 3 antibiotics of the ten different antibiotic drugs tested (Table 4). While multi-drug resistance (MDR) pattern of Gram positive bacteria isolated revealed Streptococcus spp. shows the highest resistance pattern resisting the effect of 4-6 antibiotics of the ten different antibiotic drugs tested while Staphylococcus aureus shows the lowest resistance pattern resisting the effect of just 2 antibiotics of the ten different antibiotic drugs tested (Table 6).

\subsection{Plasmid Profiles}

Some of the bacteria isolate inhabited extra-chromosomal DNA (plasmid) with molecular weight of 3.0Kbase (Table 7). Plasmids were isolated from the bacteria 
isolates using the QIAGEN Plasmid Purification mini kit. Two of the plasmid possessed bacteria were further subjected to molecular characterization and gene sequencing using Agarose gel electrophoresis.

Table 4. Antibiotic resistance pattern of Gram negative bacteria isolated from well water

\begin{tabular}{lccccccccccc}
\hline & \multicolumn{10}{c}{ Antibiotics } \\
\cline { 2 - 11 } Isolates & AMX & AUG & GEN & PEF & OFX & STP & SXT & CHM & SPF & CPX & Phenotype of resistance pattern \\
\hline Pseudomonas aeruginosa & & & & & & & & & & & \\
1 & $\mathrm{R}$ & $\mathrm{R}$ & $\mathrm{S}$ & $\mathrm{S}$ & $\mathrm{S}$ & $\mathrm{R}$ & $\mathrm{R}$ & $\mathrm{I}$ & $\mathrm{R}$ & $\mathrm{S}$ & AMX, AUG, SPT, SXT, SPF \\
2 & $\mathrm{R}$ & $\mathrm{R}$ & $\mathrm{S}$ & $\mathrm{S}$ & $\mathrm{S}$ & $\mathrm{R}$ & $\mathrm{I}$ & $\mathrm{R}$ & $\mathrm{R}$ & $\mathrm{I}$ & AMX, AUG, STP, CHM, SPF \\
3 & $\mathrm{R}$ & $\mathrm{R}$ & $\mathrm{S}$ & $\mathrm{S}$ & $\mathrm{S}$ & $\mathrm{R}$ & $\mathrm{R}$ & $\mathrm{R}$ & $\mathrm{R}$ & $\mathrm{S}$ & AMX, AUG, STP, SXT, CHM, SPF \\
4 & $\mathrm{R}$ & $\mathrm{R}$ & $\mathrm{S}$ & $\mathrm{S}$ & $\mathrm{S}$ & $\mathrm{R}$ & $\mathrm{R}$ & $\mathrm{R}$ & $\mathrm{R}$ & $\mathrm{S}$ & AMX, AUG, STP, SXT, CHM, SPF \\
5 & $\mathrm{R}$ & $\mathrm{R}$ & $\mathrm{S}$ & $\mathrm{S}$ & $\mathrm{S}$ & $\mathrm{R}$ & $\mathrm{R}$ & $\mathrm{R}$ & $\mathrm{R}$ & $\mathrm{I}$ & AMX, AUG, STP, SXT, CHM, SPF \\
\hline \% resistance to antibiotic & 100 & 100 & 0 & 0 & 0 & 100 & 80 & 80 & 100 & 0 & \\
\hline
\end{tabular}

\section{Escherichia coli}

\begin{tabular}{|c|c|c|c|c|c|c|c|c|c|c|c|}
\hline 1 & $\mathrm{R}$ & $\mathrm{R}$ & $\mathrm{R}$ & $\mathrm{S}$ & $\mathrm{S}$ & $\mathrm{R}$ & $\mathrm{S}$ & $\mathrm{R}$ & $\mathrm{R}$ & $\mathrm{I}$ & AMX, AUG, GEN, STP, CHM, SPF \\
\hline 2 & $\mathrm{R}$ & $\mathrm{R}$ & $\mathrm{S}$ & $\mathrm{S}$ & $\mathrm{S}$ & $\mathrm{R}$ & $\mathrm{S}$ & $\mathrm{S}$ & $\mathrm{R}$ & $\mathrm{S}$ & AMX, AUG, STP, SPF \\
\hline 3 & $\mathrm{R}$ & $\mathrm{R}$ & I & $\mathrm{S}$ & $\mathrm{S}$ & $\mathrm{R}$ & I & $\mathrm{S}$ & $\mathrm{R}$ & $\mathrm{S}$ & AMX, AUG, STP, SPF \\
\hline 4 & $\mathrm{R}$ & $\mathrm{R}$ & $\mathrm{S}$ & $\mathrm{S}$ & $\mathrm{S}$ & $\mathrm{S}$ & $\mathrm{I}$ & $\mathrm{I}$ & $\mathrm{R}$ & $\mathrm{I}$ & AMX, AUG, SPF \\
\hline$\%$ resistance to antibiotic & 100 & 100 & 25 & 0 & 0 & 75 & 0 & 50 & 100 & 0 & \\
\hline \multicolumn{12}{|l|}{ Enterobacter aerogenes } \\
\hline 1 & $\mathrm{R}$ & $\mathrm{R}$ & $\mathrm{S}$ & $\mathrm{S}$ & $\mathrm{S}$ & $\mathrm{I}$ & $\mathrm{S}$ & I & $\mathrm{R}$ & I & AMX, AUG, SPF \\
\hline 2 & $\mathrm{R}$ & $\mathrm{R}$ & $\mathrm{S}$ & $\mathrm{S}$ & $\mathrm{S}$ & $\mathrm{S}$ & $\mathrm{S}$ & $\mathrm{S}$ & $\mathrm{R}$ & I & AMX, AUG, SPF \\
\hline 3 & $\mathrm{R}$ & $\mathrm{R}$ & $\mathrm{R}$ & $\mathrm{S}$ & $\mathrm{S}$ & $\mathrm{I}$ & $\mathrm{I}$ & $\mathrm{R}$ & $\mathrm{R}$ & $\mathrm{S}$ & AMX, AUG, GEN, CHM SPF \\
\hline$\%$ resistance to antibiotic & 100 & 100 & 33 & 0 & 0 & 0 & 0 & 33 & 100 & 0 & \\
\hline
\end{tabular}

\begin{tabular}{|c|c|c|c|c|c|c|c|c|c|c|c|}
\hline 1 & $\mathrm{R}$ & $\mathrm{R}$ & $\mathrm{S}$ & $\mathrm{S}$ & $\mathrm{S}$ & $\mathrm{S}$ & $\mathrm{R}$ & $\mathrm{R}$ & $\mathrm{R}$ & $\mathrm{S}$ & AMX, AUG, SXT, CHM, SPF \\
\hline 2 & $\mathrm{R}$ & $\mathrm{R}$ & $\mathrm{S}$ & $\mathrm{S}$ & $\mathrm{S}$ & I & $\mathrm{R}$ & I & $\mathrm{R}$ & I & \\
\hline \% resistance to antibiotic & 100 & 100 & 0 & 0 & 0 & 0 & 100 & 50 & 100 & 0 & \\
\hline
\end{tabular}
Proteus sp.

\begin{tabular}{lccccccccccc}
1 & $\mathrm{R}$ & $\mathrm{R}$ & $\mathrm{S}$ & $\mathrm{S}$ & $\mathrm{S}$ & $\mathrm{R}$ & $\mathrm{R}$ & $\mathrm{I}$ & $\mathrm{R}$ & $\mathrm{S}$ & AMX, AUG, STP, SXT, SPF \\
\hline \% resistance to antibiotic & 100 & 100 & 0 & 0 & 0 & 100 & 100 & 0 & 100 & 0 &
\end{tabular}

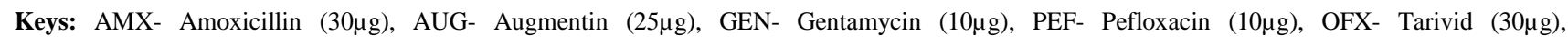

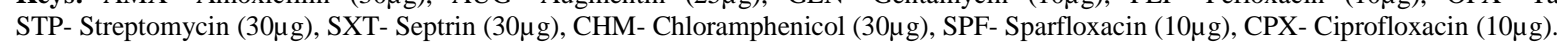

Table 5. Antibiotic resistance pattern of Gram positive bacteria isolated from well water samples

\begin{tabular}{|c|c|c|c|c|c|c|c|c|c|c|c|}
\hline \multirow[b]{2}{*}{ Isolates } & \multicolumn{10}{|c|}{ Antibiotics } & \multirow[b]{2}{*}{ Phenotype of resistance pattern } \\
\hline & AMX & ROC & CPX & STP & SXT & ERY & PEF & GEN & APX & ZIN & \\
\hline \multicolumn{12}{|l|}{ Streptococcus spp. } \\
\hline 1 & S & S & S & I & $S$ & I & S & S & $\mathrm{R}$ & S & APX \\
\hline 2 & $\mathrm{R}$ & $\mathrm{R}$ & S & $\mathrm{R}$ & $\mathrm{R}$ & I & S & $S$ & $\mathrm{R}$ & I & AMX, ROC, STP, SXT, APX \\
\hline 3 & I & $\mathrm{R}$ & S & $\mathrm{R}$ & $\mathrm{R}$ & I & S & $\mathrm{S}$ & $\mathrm{R}$ & $\mathrm{S}$ & ROC, STP, SXT, APX \\
\hline 4 & $\mathrm{R}$ & $S$ & I & I & I & I & S & $S$ & $\mathrm{R}$ & S & AMX, APX \\
\hline 5 & $\mathrm{R}$ & S & I & $\mathrm{S}$ & S & I & S & $\mathrm{S}$ & $\mathrm{R}$ & S & AMX, APX \\
\hline 6 & I & S & S & S & S & I & S & $\mathrm{S}$ & $\mathrm{R}$ & I & APX \\
\hline 7 & $\mathrm{R}$ & S & S & $\mathrm{R}$ & $\mathrm{R}$ & I & S & $\mathrm{S}$ & $\mathrm{R}$ & I & AMX, GEN, APX, ZIN \\
\hline 8 & $\mathrm{R}$ & $\mathrm{S}$ & I & I & I & I & S & $\mathrm{R}$ & $\mathrm{R}$ & $\mathrm{R}$ & AMX, GEN, APX, ZIN \\
\hline$\%$ resistance to antibiotic & 63 & 25 & 0 & 38 & 38 & 0 & 0 & 13 & 100 & 13 & \\
\hline \multicolumn{12}{|l|}{ Micrococcus spp. } \\
\hline 1 & $\mathrm{R}$ & S & I & I & $\mathrm{R}$ & I & S & $\mathrm{R}$ & $\mathrm{R}$ & $\mathrm{R}$ & AMX, SXT, GEN, APX, ZIN \\
\hline 2 & $\mathrm{R}$ & $\mathrm{R}$ & $\mathrm{S}$ & I & $\mathrm{S}$ & I & S & $\mathrm{R}$ & $\mathrm{R}$ & $\mathrm{R}$ & AMX, ROC, GEN, APX, ZIN \\
\hline 3 & $\mathrm{I}$ & $\mathrm{R}$ & I & $\mathrm{R}$ & I & $\mathrm{S}$ & $\mathrm{S}$ & $\mathrm{S}$ & $\mathrm{R}$ & I & ROC, STP, APX \\
\hline 4 & $\mathrm{R}$ & $\mathrm{I}$ & S & $\mathrm{R}$ & $\mathrm{S}$ & $\mathrm{I}$ & S & $\mathrm{S}$ & $\mathrm{R}$ & $\mathrm{I}$ & AMX, STP, APX \\
\hline \multicolumn{12}{|l|}{$\%$ resistance to antibiotic } \\
\hline \multicolumn{12}{|l|}{ Staphylococcus aureus } \\
\hline 1 & $\mathrm{R}$ & $\mathrm{I}$ & $\mathrm{S}$ & $\mathrm{I}$ & $\mathrm{S}$ & $\mathrm{I}$ & $\mathrm{S}$ & $\mathrm{I}$ & $\mathrm{R}$ & I & AMX, APX \\
\hline$\%$ resistance to antibiotic & 100 & 0 & 0 & 0 & 0 & 0 & 0 & 0 & 100 & 0 & \\
\hline
\end{tabular}

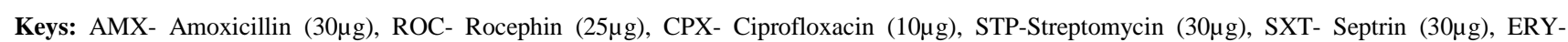

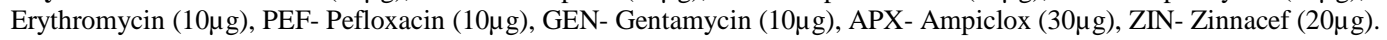


Table 6. Phenotype pattern of multiple antibiotics resistance of the isolated bacteria from well water samples

\begin{tabular}{|c|c|c|c|}
\hline Organisms & Number of antibiotics & Combination of antibiotics & Number of occurrence (\%) \\
\hline P. aeruginosa and E. coli & & AMX, AUG, STP, SPF & 2 \\
\hline Klebsiella spp. & 4 & AMX, AUG, SXT, SPF & 1 \\
\hline \multirow[t]{2}{*}{ Streptococcus spp. } & & ROC, STP, SXT, APX & 1 \\
\hline & & Total & $4(14)$ \\
\hline E. aerogenes & & AMX, AUG, GEN, CHM, SPF & 1 \\
\hline P. aeruginosa & & AMX, AUG, STP, SXT, SPF & 1 \\
\hline P. aeruginosa & & AMX, AUG, STP, CHM, SPF & 2 \\
\hline Klebsiella spp. & & AMX, AUG, SXT, CHM, SPF & 1 \\
\hline Proteus spp. & 5 & AMX, AUG, STP, SXT, SPF & 1 \\
\hline Streptococcus spp. & & AMX, STP, SXT, APX, ZIN & 1 \\
\hline Micrococcus spp. & & AMX, SXT, GEN, APX, ZIN & 1 \\
\hline Micrococcus spp. & & AMX, ROC, GEN, APX, ZIN & 1 \\
\hline \multirow[t]{2}{*}{ Streptococcus spp. } & & AMX, ROC, STP, SXT, APX & 1 \\
\hline & & Total & 10(36) \\
\hline E. coli & & AMX, AUG, GEN, STP, CHM, SPF & 1 \\
\hline P. aeruginosa & 6 & AMX, AUG, STP, SXT, CHM, SPF & 3 \\
\hline \multirow[t]{2}{*}{ Streptococcus spp. } & & AMX, STP, GEN, SXT, APX, ZIN & 1 \\
\hline & & Total & $5(18)$ \\
\hline
\end{tabular}

Table 7. Plasmid profile and multidrug resistance patterns of selected bacterial isolates from hand-dug well water

\begin{tabular}{lccc}
\hline Isolates & Molecular weight $(\mathrm{Kb})$ & \multicolumn{2}{c}{ Antibiotics to which the isolates were resistant } \\
\cline { 3 - 4 } & & Number & Combination \\
\hline Klebsiella aerogenes & 3.0 & 4 & AMX, AUG, STP, CHM \\
Escherichia coli & 3.0 & 6 & AMX, AUG, GEN, STP, CHM, SPF \\
Enterobacter aerogenes & 3.0 & 5 & AMX, AUG, GEN, CHM, SPF \\
\hline
\end{tabular}

Key: AMX-Amoxicillin, AUG-Augmentin, STP-Streptomycin, GEN-Gentamycin, CHM-Chloramphenicol, SXT-Septrin and SPF-Sparfloxacin. KbKilobase.

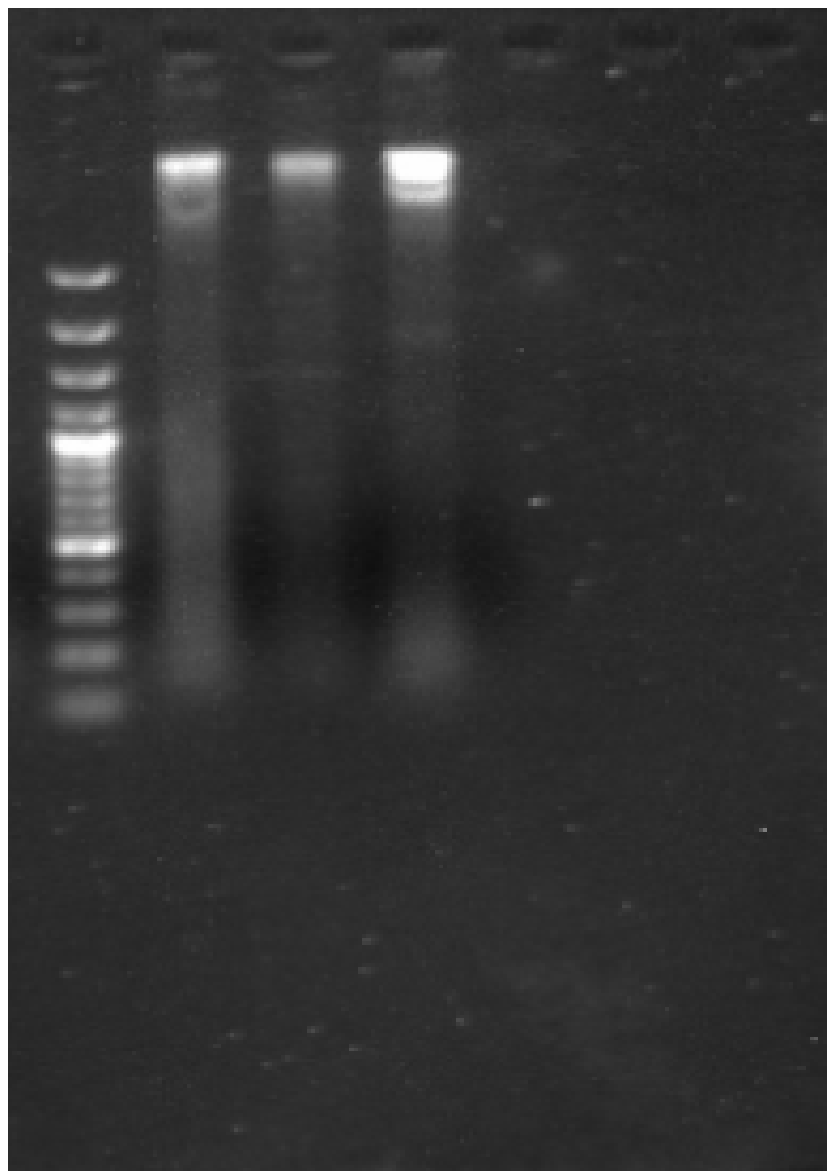

Figure 1. Plasmid profile of the multiple antibiotic resistance bacteria isolates

\subsection{DNA Extraction of Multiple Antibiotic Resistant Bacteria Isolates}

Multiple antibiotic resistant bacteria, Escherichia coli and Enterobacter aerogenes were screened for DNA associated with the resistance pattern of the antibiotics to which they were resistant to. They were found to possess different genes for different antibiotic type which indicated that the resistant genes were encoded in the isolated DNA. Figure 2 shows the DNA profile of multiple antibiotic resistant Escherichia coli and Enterobacter aerogenes to streptomycin. Isolates (E. coli and Enterobacter aerogenes) possessed aadA gene which confirmed resistance to the antibiotic streptomycin with positive amplification of approximately 447bp indicating gene presence. Figure 3 shows the DNA profile of multiple antibiotic resistant Escherichia coli and Enterobacter aerogenes to Gentamycin. Isolates (E. coli and Enterobacter aerogenes) possessed aac(3)-IV gene which confirmed resistance to the antibiotic gentamycin with positive amplification of approximately 286bp indicating gene presence. Figure 4 shows the DNA profile of multiple antibiotic resistant Escherichia coli and Enterobacter aerogenes to chloramphenicol. Isolates possessed catA1 gene which confirmed resistance to the antibiotic chloramphenicol with positive amplification of approximately 540bp indicating gene presence. Figure 5 shows the DNA profile of multiple antibiotic resistant Escherichia coli and Enterobacter aerogenes to sparfloxacin. Isolates (E. coli and Enterobacter aerogenes) possessed aadA gene which confirmed resistance to the antibiotic sparfloxacin with positive amplification of approximately 670bp indicating gene presence. 


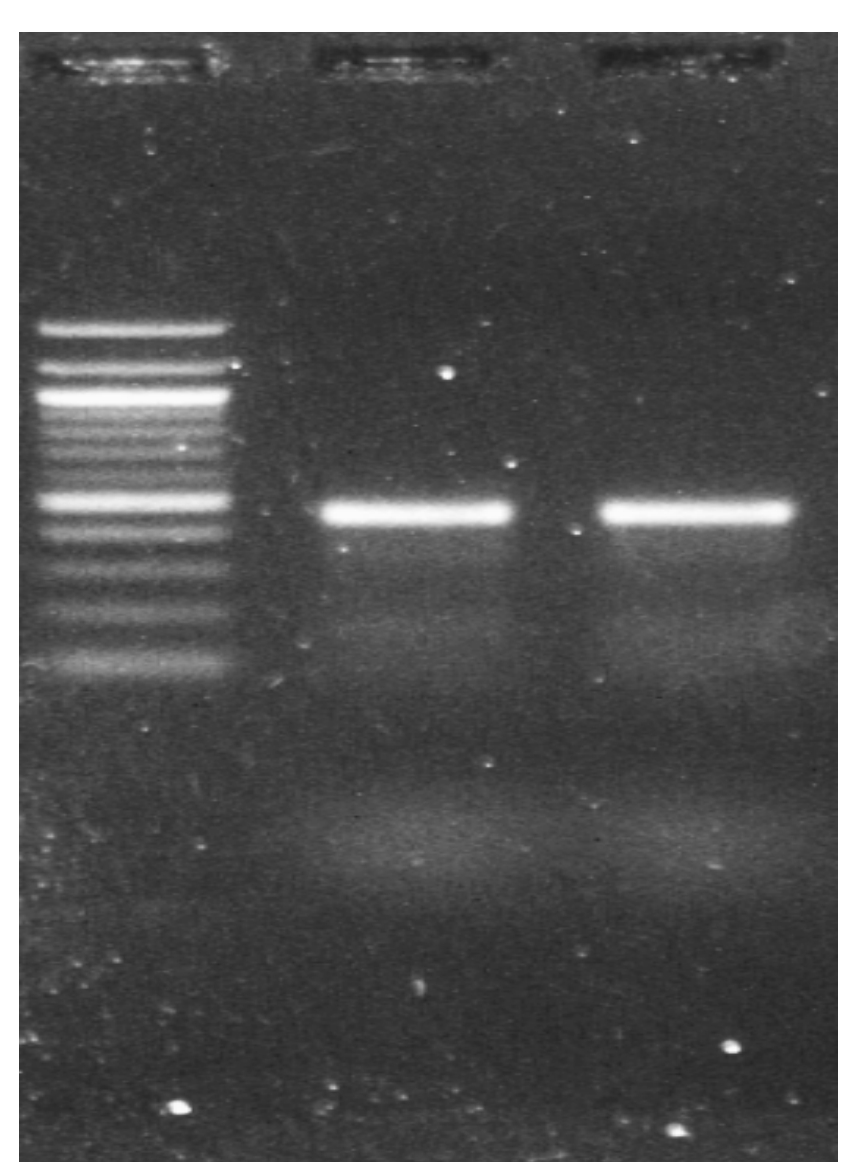

Figure 2. DNA profile of multiple antibiotic resistance E. coli and Enterobacter aerogenes to streptomycin

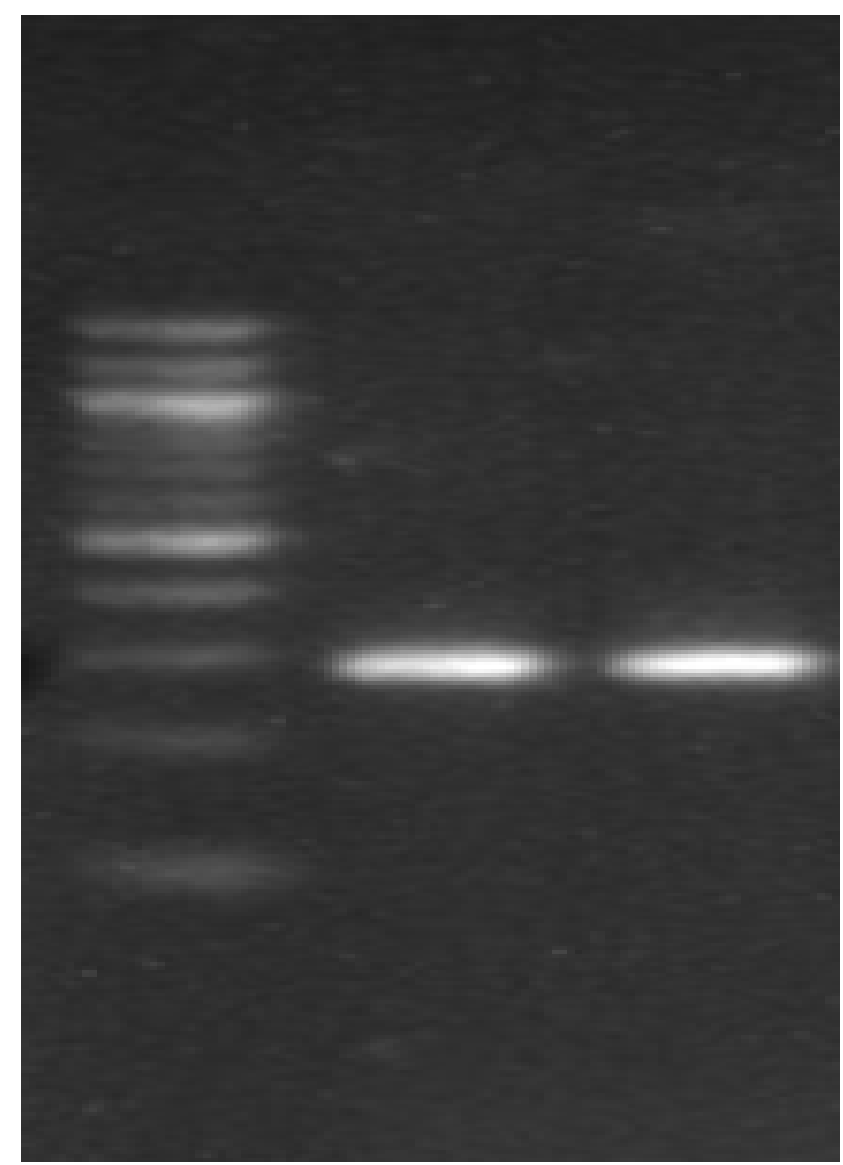

Figure 3. DNA profile of multiple antibiotic resistance E. coli and Enterobacter aerogenes to gentamycin

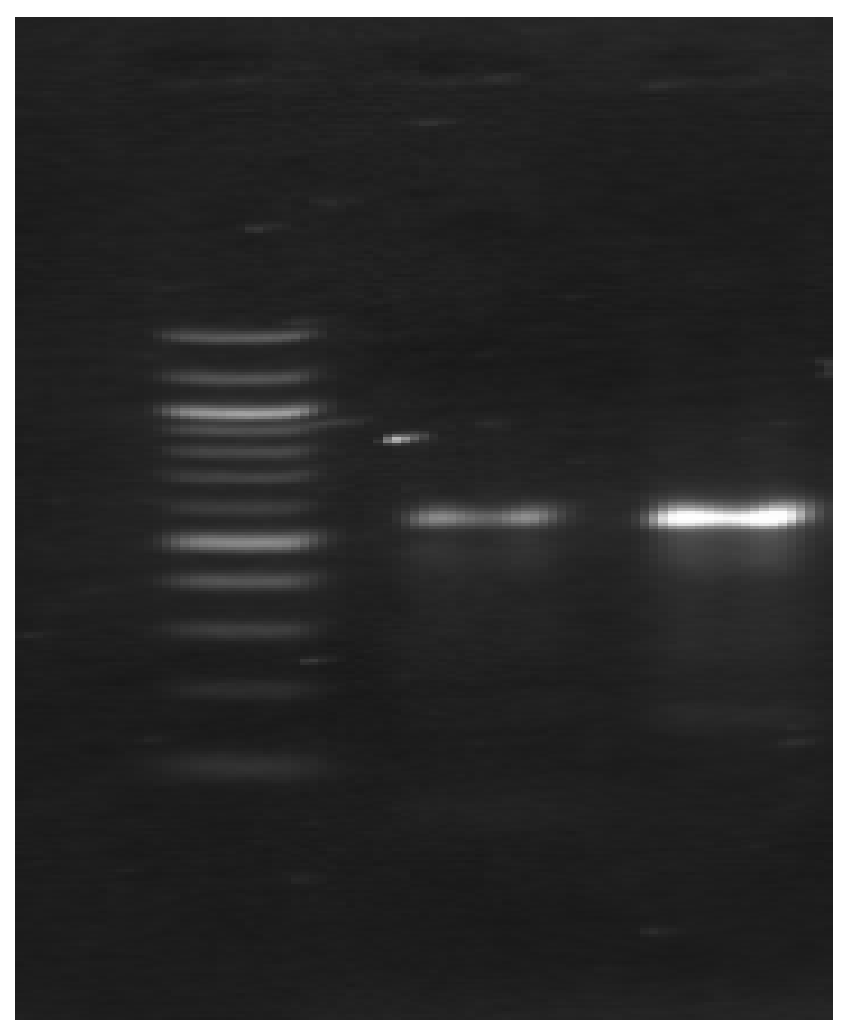

Figure 4. DNA profile of multiple antibiotic resistance E. coli and Enterobacter aerogenes to chloramphenicol

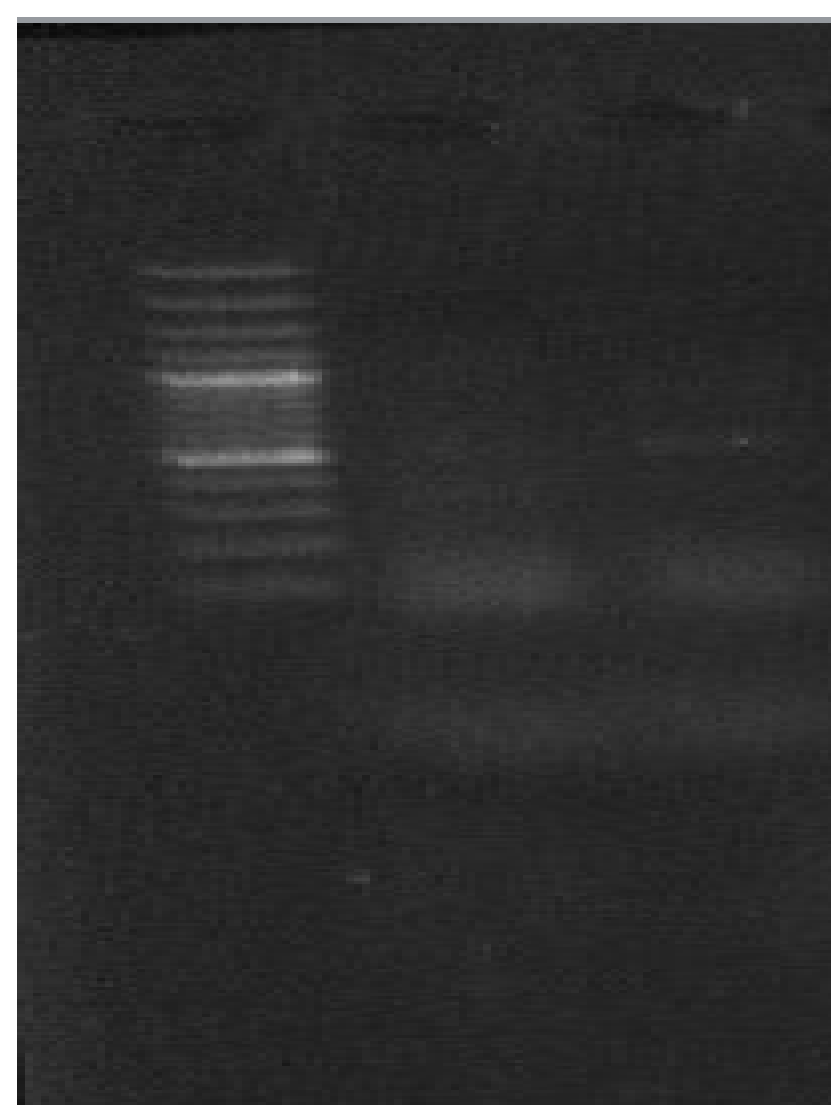

Figure 5. DNA profile of the multiple antibiotic resistance E. coli and Enterobacter aerogenes to sparfloxacin

Molecular characterization and gene sequencing of the plasmid possessed bacteria

The nucleotide sequences of Escherichia coli strain s1428 and Enterobacter aerogenes strain 341 as shown in 
chart 1 and chart 2 respectively as analyzed using the BLAST bioinformatics suite on the NCBI.

Chart 1: Partial sequence Escherichia coli strain s1428 16S ribosomal RNA gene

AATCCAGTCGAAAGGTAACAGGAAACAGCTTG CTGTTTCGCTGACGAGTGGCGGACGGGTGAGTAA TGTCTGGGAAACTGCCTGATGGAGGGGGATAACT ACTGGAAACGGTAGCTAATACCGCATAACGTCGC AAGACCAAAGAGGGGGACCTTCGGGCCTCTTGCC ATCGGATGTGCCCCGATGGGATTAGCTAGTAGGT GGGGTAACGGCTCACCTAGGCGACGATCCCTAGC TGGTCTGAGAGGATGACCAGCCACACTGGAACTG AGACACGGTCCAGACTCCTACGGGAGGCAGCAG TGGGGAATATTGCACAATGGGCGCAAGCCTGATG CAGCCATGCCGCGTGTATGAAGAAGGCCTTCGGG TTGTAAAGTACTTTCAGCGGGGAGGAAGGGAGTA AAGTTAATACCTTTGCTCATTGACGTTACCCGCA GAAGAAGCACCGGCTAACTCCGTGCCAGCAGCC GCGGTAATACGGAGGGTGCAAGCGTTAATCGGA ATTACTGGGCGTAAAGCGCACGCAGGCGGTTTGT TAAGTCAGATGTGAAATCCCCGGGCTCAACCTGG GAACTGCATCTGATACTGGCAAGCTTGAGTCTCG TAGAGGGGGGTAGAATTCCAGGTGTAGCGGTGA AATGCGTAGAGATCTGGAGGAATACCGGTGGCG AAGGCGGCCCCCTGGACGAAGACTGACGCTCAG GTGCGAAAGCGTGGGGAGCAAACAGGATTAGAT ACCCTGGTAGTCCACGCCGTAAACGATGTCGACT TGGAGGTTGTGCCCTTGAGGCGTGGCTTCCGGAG CTAACGCGTTAAGTCGACCGCCTGGGGAGTACGG CCGCAAGGTTAAAACTCAAATGAATTGACGGGG GCCCGCACAAGCGGTGGAGCATGTGGTTTAATTC GATGCAACGCGAAGAACCTTACCTGGTCTTGACA TCCACGGAAGTTTTCAGAGATGAGAATGTGCCTT CGGGACCGTGAGACAGGTGCTGCATGGCTGTCGT CAGCTCGTGTTGTGAAATGTTGGGTTAAGTCCCG CAACGGCGCAACCCTTATCCTTTGTTGCCAGCGG TCCGGCCGGGAACTCAAAGGAGACTGCCAGTGAT AAACTGAGGAAGGTGGGGATGACGTCAAGTCAT CATGGCCCTTACGACCAGGGCTACACACGTGCTA CAATGGCGCATACAAAGAGAAGCGACCTCGCGA GAGCAAGCGGACCTCATAAAGTGCGTCGTAGTCC GGATTGGAGTCTGCAACTCGACTCCATGAAGTCG GAATCGCTAGTAATCGTGGATCAGAATGCCACGG TGAATACGTTCCCGGGCCTTGTACACACCGCCCG TCACACCATGGGAGTGGGTTGCAAAAGAAGTAG GTAGCTTAACCTTCGGGAGGGCGCTTACCACTTT GTGATTCAACTA

Chart 2: Partial sequence of Enterobacter aerogenes strain 341 16S ribosomal RNA gene

GCTTAACATGCAGTCGAACGGTAACAGGAAGC AGCTTGCTGCTTCGCTGACGAGTGGCGGAGGGGT GAGTAATGTCTGGGAAACTGCCTGATGGAGGGG GATAACTACTGGAAACGGTAGCTAATACCGCATA ACGTCGCAAGACCAAAGAGGGGGACCTTCGGGC CTCTTGCCATCGGATGTGCCCAGATGGGATTAGC TAGTAGGTGGGGTAACGGCCCACCTAGGCGACG ATCCCTAGCTGGTCTGAGAGGATGACCAGCCACA TGGAACTGAGACACGGTCCAGACTCCTACGGGAG GCAGCAGTGGGGAATATTGCACAATGGGCGCAA GCTGATGCAGCCATGCCGCGTGTATGAAGAAGGC CTTCGGGTTGTAAAGTACTTTCAGCGGGGAGGAA GGCGATAAGGTTAATAACCTTGTCGATTGACGTT ACCCGCAGAAGAAGCACCGGCTAACTCCGTGCCA
GCAGCCGCGGTAATACGGAGGGTGCAAGCGTTA ATCGGAATTACTGGGCGTAAAGCGCACGCAGGC GGTCTGTCAAGTCGGATGTGAAATCCCCGGGCTC AACCTGGGAACTGCATTCGAAACTGGCAGGCTAG AGTCTTGTAGAGGGGGGTAGAATTCCAGGTTTAG CGGTGAAATGCGTAGAGATCTGGAGGAATACCG GTGGCGAAGGCGGCCCCCTGGACAAAGACTGAC GCTCAGGTGCGAAAGCGTGGGGAGCAAACAGGA TTAGATACCCTGGTAGTCCACGCCGTAAACGATG TCGACTTGGAGGTTGTGCCCTTGAGGCGTGGCTT CCGGAGCTAACGCGTTAAGTCGACCGCCTGGGGA GTACGGCCGCAAGGTTAAAACTCAAATGAATTGA CGGGGGCCCGCACAAGCGGTGGAGCATGTGGTTT TATTCGATGCAACGCGAAGAACCTTACCTACTCT TGACATCCAGAGAACTTTCCAGAGATGGATTGGC TGCCTTCGGGAACTCTGAGACAGGTGCTGCATGG CTGTCGTCAGCTCGTGTTGTGAAATGTTGGGTTA AGTCCCGCAACGAGCGCAACCCTTATCCTTTGTT GCCAGCGGTCCGGCCGGGAACTCAAAGGAGACT GCCAGTGATAAACTGGAGGAAGGTGGGGATGAC GTCAAGTCATCATGGCCCTTACGAGTAGGGCTAC ACACGTGCTACAATGGCGCATACAAAGAGAAGC GACCTCGCGAGAGCAAGCGGACCTCATAAAGTG CGTCGTAGTCCGGATTGGAGTCTGCAACTCGACT CCATGAAGTCGGAATCGCTAGTAATCGTGGATCA GAATGCCACGGTGAATACGTTCCCGGGCCTTGTA CACACCGCCCGTCACACCATGGGAGTGGGTTGCA AAAGAAGTAGGTACCATC

\subsection{Physicochemical Estimations}

All water samples were observed to be colourless and odourless. The value range for the parameters analyzed is depicted in Table 9 as follows: temperature (21.2 - 26.3) ${ }^{\circ} \mathrm{C}$, turbidity (0.4 - 0.8) NTU, conductivity (0.24 - 0.34) $\mu \mathrm{S} / \mathrm{cm}, \mathrm{pH}(6.4-7.5)$, total dissolved solid (189 - 390) mg/L, total solid (44.3 - 46.8) mg/L, total alkalinity (27.1 - 28.7) $\mathrm{mg} / \mathrm{L}$, acidity as $\mathrm{CaCO}_{2}(2.2$ - 2.6) $\mathrm{mg} / \mathrm{L}$, total hardness (22.3 - 23.4) mg/L, chloride (21.0 - 22.9) mg/L, sulphate $(5.1$ - 5.7) $\mathrm{mg} / \mathrm{L}$, nitrate $(0.3-0.4) \mathrm{mg} / \mathrm{L}$ and magnesium (0.2 - 0.5) mg/L.

\section{Discussion}

The physicochemical parameters derived from this study revealed values generally within the range recommended by [17]. But, the level of contamination with bacteria was higher than the permissible limits. The key to providing microbiologically safe water lies in understanding the mechanisms by which water gets contaminated and formulating interventions at critical points to decrease and prevent contamination of well water for drinking and other domestic purposes [18]. Physical parameters such as $\mathrm{pH}$, temperature and total dissolved solids (TDS) content have a major influence on bacterial growth. The $\mathrm{pH}$ value ranging from 3-10.5 could favour both indicator and pathogenic organism's growth [19]. The $\mathrm{pH}$ provided information about acidity or alkalinity [20] which also a means of collecting other characteristics or behaviour such as corrosive acidity [21]. Eye irritation and exacerbation of skin disorder have been associated with $\mathrm{pH}$ value greater than 11 . With respect to the well water samples, 
the $\mathrm{pH}$ values were in safe limits. High TDS was commonly objectionable or offensive to taste. A higher concentration of TDS usually serves no health threat to human until the value exceeds $10,000 \mathrm{mg} / \mathrm{l}$ [22]. The TDS of all the 12 samples were within the permissible limit.

The assessment of microbiological quality of water from different well water samples was essential for detecting the presence or absence of organisms that might constitute health hazards in water, which could be used as a guide to monitor and protect the water source. The total bacteria counts for all the samples were generally high, exceeding the limit of $1.0 \times 10^{2} \mathrm{CFU} / \mathrm{ml}$ which was the standard limit of heterotrophic count for drinking water [23].

The high total plate counts observed in the well water samples indicated the presence of high organic matter and related nutrient sources. The likely primary source of bacterial contamination might include the surface run-off, sewage treatment facilities, natural soil/plants bacteria and improper management activities of the inhabitants like washing refuse disposal, faecal droppings, dipping of different fetching materials inside those water source which were observed among most of the wells at Osekita, Iworoko-Ekiti. Heritage hostel well water had the highest number of coliform which was due to environmental contamination as a result of proximity of the well to soak away and bush area.

Various groups of microorganisms isolated and identified during this study have one pathogenic effect or the other. Streptococcus spp. is known to both slow human cilia beating and damage respiratory epithelium invitro [24]. Micrococcus spp. is a natural part of the skin's microflora although it has been found to cause recurrent infections such as bacteremia, septic shock, arthritis, meningitis and cavitating pneumonia in immune-compromised patients [25]. Pseudomonas aeruginosa is an example of non faecal coliform that causes endocarditis, pneumonia (respiratory tract infection), bacterimia and diarrhoea. The Staphylococcus species is known to produce enterotoxin [26]. Proteus sp is an intestinal flora, but also widely distributed in soils and water [27]. The presence of some of these organisms signifies and is indicative of water contamination from some domestic sources. Although, water from these wells may look clean and have no undesirable odour or taste, pathogens found in such water could be harmful by causing serious illnesses. Mercy domain hostel well water sample had the lowest bacterial counts which could be due to its depth, properly covered, the use of single clean fetcher and its distance away from refuse dump site which is in agreement with the report of [28].

The total coliform counts for the well water samples examined during this study were exceedingly high as against the EPA maximum contamination level (MCL) for coliform bacteria in drinking water of zero total coliform per $100 \mathrm{ml}$ of water [23]. The high coliform counts obtained in the well water analyzed may be an indication that the well water samples were faecally contaminated $[23,29]$. None of the well water samples in this study complied with the EPA standard for colifoms in water.

The isolated bacteria species were identified to be the same with those commonly encountered in water and aquatic environment which is similar to the study on stream surface water in Wyoming in USA as reported by [30] and reviewed by [26,31]. The high number of bacteria present in this water and the fact that they belong to the family of Enterobacteriaceae and quite a considerable number of coliform constitute enough evidence that the water from this sources are not portable and so unfit for human consumption. They differ significantly from internationally accepted standards for portable water. The implication is that they constitute a serious risk to the public health.

Drug resistance could be transferred between members of Enterobacteriaceae which was discovered 30years ago has focused attention on infections, drug resistance plasmids and the bacteria carrying them. This observation in conjunction with the selection pressure imposed by antibiotic usage has increased the incidence of pathogenic strains that have acquired antibiotic resistance [32]. Many of the microorganisms resistance to antibiotics haboured plasmids as reported by [33].

In this study, antibiotic-resistant bacteria were widespread in all the well water samples obtained from different hostels, although this is not surprising because the intrinsic resistance of many organisms to antibiotics is well documented [34]. However, a partial potency of some of the tested drugs like gentamycin, pefloxacin, tarivid and ciprofloxacin were observed. Most of the isolated bacteria showed multiple antibiotic resistances which is significant health-wise. Following the earlier report of some researchers, most antibiotics are naturally produced by soil organisms and as such, these organisms possess the ability to detoxify the effects of these antibiotics, thus having little or no effect on them $[35,36]$. The risk becomes more significant as many of the multiple antibiotic resistant bacteria were detected to be carrying plasmid(s) as well as DNA encoding for multiple antibiotic resistance to different antibiotic types. This agrees with the work of McPherson and Gealt that reported several enteric bacterial stains to possess antibiotic resistance and high molecular weight plasmids, as well as antibiotic resistant DNA, hence transfer their resistance to other recipient bacteria [37]. The transmissibility of resistance genes and plasmids elevates the challenge, considering the vast potential of hosts presented by microbial populations in the water environment [4].

The bacteria isolates were screened for plasmids and were found to be carrying plasmids of high molecular weight of $3.0 \mathrm{~Kb}$ ase, which indicated that the multiple resistance genes are coded on plasmids. Two of the plasmid possessed bacteria isolates (Escherichia coli and Enterobacter aerogenes) were further subjected to molecular characterization and gene sequencing. Multiple antibiotic resistant bacteria, Escherichia coli and Enterobacter aerogenes were screened for DNA associated with the resistance pattern of the antibiotics to which they were resistant to. They were found to possess different resistance genes for different antibiotic type which indicated that the resistant genes were encoded in the isolated DNA.

This study has clearly shown that water from wells at Oseikita, Iworoko-Ekiti harbour multiple antibiotic resistant bacteria strains and as such, individuals drinking this water or using it for other domestic purposes may ingest resistant strains which could become part of the human microflora. As a result of selection pressure, such 
organisms may establish themselves within the individuals and become predominant microflora. Therefore, infections caused by such organisms are very difficult to treat [34].

\section{Conclusion}

This study has clearly shown that there is a high incidence of bacterial contamination of well waters collected from hostels at Osekita, Iworoko-Ekiti have numerous multiple antibiotic resistance pathogenic organisms which make the water sources unsuitable to produce water for drinking without proper processing or treatment. The molecular and phylogenetic identity of the organisms was determined by $16 \mathrm{~S}$ rDNA and DNA sequence analysis; revealing the identity of microbes involved to be Escherichia coli strain s1428 and Enterobacter aerogenes strain 341. The DNA sequence BLAST analysis indicated a high similarity of the obtained sequence corresponding 99\% to Escherichia coli strain s1428 and Enterobacter aerogenes strain 341.

Public awareness on the dangers associated with the consumption of contaminated water should be increased. To reduce the widespread incidence of contamination of well water, it is advocated that well dug must be deep and covered adequately. Also, good personal and environmental sanitary practices must be maintained in and around the wells as well as the use of a single, clean drawing fetcher. The construction of pit latrines near wells must be avoided.

\section{Conflict of Interests}

The authors declare they have no conflict of interests.

\section{References}

[1] Onifade, A.K. and Ilori, R. M. (2008). Microbiological analysis of sachet water vended in Ondo state, Nigeria. Environ. Res. J., 2: 107-110.

[2] Obi, C. N., Okocha, C. O. (2007). Microbiology and physicochemical analysis of selected borehole waters. Journal of Engineering and Applied Science, 25(7): 920-929.

[3] Osei, A. Y. (2005). New School Chemistry for Senior Secondary Schools. African First Publisher Ltd, Ontsha, Third Edition, 292.

[4] Vincent, N. C., Veronica, J. U., Stella, I. S., Etinosa, O. I. and Anthony, I. O. (2010). Multidrug resistance and plasmid patterns of Escherichia coli 0157 and other E. coli isolated from diarrheal stools and surface waters from some selected sources in Zaria, Nigeria. Int. J. Environ. Res. Public Health, 7:3831-3841.

[5] Abaje, I. B., Ati, O. F. and Ishaya, S. (2009). Nature of portable water supply and demand in Jema's local Government area Kaduna State, Nigeria. Research Journal of Environment and Earth Science, 1(1): 16-21.

[6] Committee on Environmental Health and Committee on Infectious Diseases (2009). Drinking Water from Private Wells and Risks to Children. American Academy of Pediatrics, (123) 6: 1599-1605.

[7] Maier, R. M., Pepper, I. L. and Gerba, C. P. (2000). Environmental Microbiology. Academic Press. San Diego, CA.

[8] Dutta, C. and Pan, A. (2002). Horizontal gene transfer and bacterial diversity; J. Biosci., 27: 27-33

[9] Olutiola P. O., Famurewa, O., Sonntag, H. S. (2000). An Introduction to General Microbiology (A practical Approach). Measurement of Microbial Growth, pp. 101-111.

[10] Monica, Cheesbrough (2006). District Laboratory Practical in Tropical Countries. Cambridge University Press, Edinburg building, Trumpington street, Cambridge CB2 1IR, United Kingdom (Antimicrobial sensitivity testing), pp. 132-148.

[11] Clinical Laboratory Standards Institute (2008). Performance standards for antimicrobial disk and dilution susceptibility tests for bacteria isolated from animals. 3rd edition. Wayne (PA): M31-A3.

[12] Dutta, S., Rajendran, K. and Roy, A. (2002). Shifting serotypes, plasmid profile analysis and antimicrobial resistance pattern of Shigella strains isolated from Kolkata, India during 1995-2000. Epidemiol Infect, 129: 235-243.

[13] Inceoglu, O., Hoogwout E. F., Hill, P. and van Elsas, J. D. (2010). Effect of DNA extraction method on the apparent microbial diversity of soil. Appl Environ Microbiol, 76: 3378-3382.

[14] Edema, M. O., Omemu, A. M. and Fapetu, O. M. (2001). Microbiological and physicochemical analysis of different sources of drinking water in Niger, Nigeria. Journal of Microbiology, 15(1): 57-61.

[15] Ademoroti, C.M.A (1996). Standard methods for water and effluent analysis Ibadan. Foludex Press Limited, pp. 10-19.

[16] AOAC. (2005). Official Methods of analysis of the Association of Analytical Chemists International, 18th ed. Gathersburg, MD U.S.A Official methods, 2005. 08.

[17] World Health Organization (WHO), (2004). Water Sanitation and Health Programme, Managing water in the home: accelerated health gains from improved water sources. World Health Organization. www.who.int.WHO/UNICEF (2004).

[18] Travett, A.F., Carter, P., Tyrel, S. (2004). Water quality deterioration: a study of household drinking water quality in rural Hunduras. International Journal Environ Health Research, 14: 273-283.

[19] Zamxaka, M., Pironcheva, G. and Muyiwa, N.Y. (2004). Microbiological and Physicochemical Assessment of the Quality of Domestic Water Sources in Selected Rural Communities of the Eastern Cape Province, South Africa. Water.SA, 30: 333.

[20] Katyal, M. and Satake, M. (1990). Total Environmental Pollution. Annual PublicationIndia, 57-59.

[21] Ghandour, E.M., Kahil, J. B., Atta, S.A. (1985). Distribution of carbonates, bicarbonates and $\mathrm{PH}$ values in ground water of Nile Delta Region of Egypt. Ground Water, 23: 35-41.

[22] Anonymous (1997). Ground water quality. Ohio department of natural resources division of water fact sheet. 1997 October 14. http://www.dms.state.oh.us/water/pubs/pdfs/fctsht4.

[23] Environmental Protection Agency (EPA) (2002). Safe Drinking Water Act Amendment. http://www.epa.gov/safe/mcl/Html.

[24] Bhakdi, S. and Tranum-jensen, J. (2003). Complement activation and attack on autologous cell membranes induced by StreptolysinO. Infect Immun., 47(1): 52-60.

[25] Smith, K. J., Neafie, R., Yeager, J. and Skelton, H. G. (1999). Micrococcus folliculitis in HIV-1 disease. British journal of dermatology, 141(3): 558-561.

[26] Okonkwo, I. O., Adejoye, O. D., Ogunnusi, T. A., Fajobi, E. A. and Shitti, O. B. (2008). Microbiology and physicochemical analysis of different water samples used for domestic purposes in Abeokuta and Ojota, Lagos State, Nigeria. African Journal of Biotechnology, 7(5): 617-621.

[27] Schlegel, H.G. (2002). General Microbiology. $7^{\text {th }}$ Edition Cambridge University Press, P480.

[28] Bitton, G. (1994). Waste Water Microbiology. Gainesville, New yorkWiley-Liss, p.118.

[29] Osunide, M.I. and Enuezie, N.P. (1999). "Bacteriological analysis of ground water” Nig. I. Microbiol, 13: 47-54.

[30] Clerk and Norris (1999). Nutrient lead and pollution study of some selected areas in Northern America available online at www.springerlink .com. p.107 Accessed 20 $0^{\text {th }}$ February, 2010.

[31] Banwo, K. (2006). Nutrient load and pollution study of some selected stations along Ogunpa River in Ibadan, Nigeria. M.sc Dissertation University of Ibadan, p. 107.

[32] Raymond, F. (1992). Le problem dis ean dans le monde (problems of water), EB and sons LTD UK, pp123-126.

[33] Richman, M. (1999). Industrial water pollution, 5(2): 24-29.

[34] Ajayi, A.O. and Akonai, K.A. (2003). Antibiotic profile of microorganisms encountered in Lagos, Nigeria. Journal of Science, 12(1\&2) 30-35.

[35] Christian, S., Riesenfeld, R., Goodman, M. and Handelsman, J. O. (2004). Uncultured soil bacteria are a reservoir of new antibiotic resistance genes. Environmental microbiology, 6(9): 981-989. 
[36] Odeyemi, A. T., Dada, A. C. Ogunbanjo, O. R. and Ojo, M. A. (2010). Bacteriological, Physicochemical and Mineral studies on Awedele spring water and soil samples in Ado-Ekiti, Nigeria. African Journal of Environmental Science and Technology, 4(6): 319-327.
[37] McPherson, P. and Gealt, M. (1986). Isolation of indigenous wastewater bacteria strains capable of mobilizing plasmid pBR325. Appl. Environ. Microbiol, 51: 904-909. 